\title{
Morte e Sono na arte grega: notas de iconografia funerária
}

\author{
HAIGANUCH SARIAN \\ Faculdade de Filosofia, Letras e Ciências Humanas \\ Depto. de Antropologia - Museu de Arqueologia e Etnologia \\ Universidade de São Paulo
}

\begin{abstract}
RESUMO: Morte e Sono têm expressões figurativas na arte grega e, através de um confronto com a tradição literária, evidenciamos crenças, elaboração poética e comportamento religioso. São analisados textos de Hesíodo, Heráclito e Pausânias, sem contar a versão homérica da morte de Sarpedão. Alguns registros na arte grega cerâmica dos séculos VI e V a.C. apontam duas tradições iconográficas referentes a Morte e Sono, a saber: a versão contrastada dessas duas entidades divinas transmitida pela arca de Cípselo na menção de Pausânias e por Heráclito de Éfeso; a versão heróica, homérica, cujo exemplar imagético mais importante é a cratera de Eufrônio.
\end{abstract}

PALAVRAS-CHAVE: Thánatos, Hýpnos, arte grega, tradição iconográfica, tradição literária, iconografia funerária.

Thánatos, nome grego da Morte, tem expressão figurativa em algumas obras arcaicas e clássicas (sécs. VI e V a.C.) que se conservaram até hoje, ou se perderam mas deixando testemunho na tradição textual. $O$ exame dessas representações permite uma reflexão sobre a iconografia da Morte, sobretudo em cenas funerárias onde intervém em "pessoa" juntamente com o seu duplo e irmão gêmeo Hýpnos, o Sono. Acrescente-se que, quando se fala em personificação de Morte e Sono, deve-se ter em mente a especificidade do termo "pessoa" em se tratando da religião grega, cujos traços característicos são "de dar às forças do além uma figura individual bem delineada e um aspecto plenamente humano"; nem por isso entendem-se como "pessoas", mas unicamente como "forças" (Vernant: 277 e 284).

As associações possíveis com a concepção de Morte e Sono na tradição literária, o confronto entre arte, cultura material e literatura, deixam transparecer crenças onde se evidenciam a elaboração poética e o comportamento religioso.

A mais antiga representação da Morte conhecida segue de perto a versão de que dispomos da sua genealogia transmitida pelo v. 212 da Teogonia de Hesíodo (final do séc. VIII/ início do séc. VII a.C.), a qual menciona ser ela, Thánatos, filho de $N y ́ x$, a Noite, e irmão gêmeo de Hýpnos, o Sono. É desde já surpreendente que o nome da Morte seja em grego masculino, uma 

notas de iconografia funerária.

vez que na Grécia antiga são fortes e poderosas as entidades femininas com natureza e função ctônicas - Keres, Moiras, Erínias, Górgones e outras mais. Porém, ao mundo dos mortos, ligamse também Hades, o deus do Inferno, divindade masculina, como ainda Hermes e Caronte.

A versão da Teogonia inspira a imagem em baixo-relevo da arca de Cípselo, ex-voto dos Cipsélidas de Corinto à deusa Hera em seu santuário de Olímpia, obra perdida e da qual subsiste uma minuciosa descrição em Pausânias (V, 18, 1-2): imagem particular dos gêmeos, ainda crianças nos braços da Noite, consiste em exemplar isolado na iconografia dessas personificações. A arca de Cípselo, cuja reconstituição foi possível através de comparações com o repertório iconográfico contemporâneo, pode ser datada de 570 a.C.. Era sem dúvida uma obra de arte: feita de cedro e decorada com ricas incrustações de ouro e marfim, particulariza o gosto da época pela arte narrativa inspirada na mitologia. As cenas figuradas se distribuem em cinco zonas horizontais superpostas: três zonas imitam as frisas contínuas jônicas, acima, abaixo e no centro, e essas são intercaladas por frisas de tipo dórico, em métopas; na penúltima zona, a métopa da extremidade esquerda recebe a imagem que nos interessa (Schefold: fig. 26). Pausânias, no séc. II d.C., viu essa arca no santuário de Hera em Olímpia e à sua descrição acrescenta, ao se referir a esse quadro, tratar-se de uma "mulher, tendo no braço direito uma criança branca adormecida e no outro (o braço esquerdo) uma criança negra semelhante a quem dorme, os dois com os pés com orientações opostas". E continua: "as inscrições são claras, mas sem elas poder-se-ia adivinhar que as duas crianças são Thánatos e Hýpnos com sua mãe Nýx, a Noite" (fig. 1). Perdura na reconstituição a dúvida a respeito da diferenciação da cor, e a iconografia posterior nos levará a um esclarecimento melhor a esse respeito.

A versão hesiódica, nos versos 758-766 da Teogonia, nos dá mais uma imagem contrastada de Morte e Sono: se ambos são "terríveis deuses", Hýpnos no entanto é "tranqüilo e doce aos homens" e Thánatos tem o "coração de ferro e a alma de bronze" e é "odioso até aos deuses imortais".

Esses contrastes nem sempre são perceptíveis na expressão imagética dessas divindades. Pouco restou da estatuária arcaica e clássica, mas temos notícia de algumas obras: é de novo

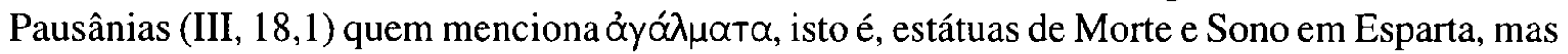
não as caracteriza. De modo que são as pinturas nos vasos áticos do final do séc. VI e do séc. V a.C. que nos fornecem o essencial sobre a iconografia desses deuses.

São frequientes as representações de Thánatos e Hýpnos adultos, alados como a maioria das abstrações na arte grega, em cenas de rara beleza e poesia onde exercem a função de понпоí, portadores do herói morto após ter-se singularizado na guerra. Se em algumas delas se pode identificar o herói Memnão, conforme a tradição dos poemas cíclicos como o Aithiopolis, o modelo homérico é, nessas cenas, indubitável, sobretudo quando as figuras são acompanhadas de inscrições entre as quais a que nomeia o herói morto - Sarpedão, caído na guerra de Tróia pela força de Pátroclo e cujo combate, morte e funerais aparecem na Ilíada XVI, 419-683 e especialmente nos versos 671-675; são os "deuses gêmeos", os "portadores rápidos", Thánatos e Hýpnos que Zeus encarrega de transportar o corpo do herói para ser enterrado, de acordo com os costumes, pelos seus parentes em sua pátria, a Lícia.

A mais extraordinária pintura do translado do corpo de Sarpedão por Morte e Sono, acompanhados e guiados por Hermes, se vê em uma cratera grega de produção ateniense, assinada pelo oleiro Euxiteo e o pintor Eufrônio (figura 2): exemplar de 510 a.C., pintado na técnica de figuras vermelhas, é enriquecido pela excelência do traçado indicando a musculatura dos corpos, sobretudo o de Sarpedão que jaz inerte, com as marcas dos ferimentos sangrando, aos cuidados dos deuses que exercem a funesta função de trensportar o guerreiro; Thánatos e Hýpnos de cada lado; no centro, Hermes psykhopompós, o condutor de almas. Morte e Sono são concebidos como dois guerreiros alados idênticos. A cratera do Louvre (figura 3) representa possivelmente o mesmo episódio e é posterior à cratera de Eufrônio. Mas a concepção é outra. Uma só inscrição 
identifica Hýpnos e toda a atmosfera guerreira da cena desaparece por completo: Thánatos e Hýpnos são figuras nuas e aladas, pouco maiores do que as constantes abstrações representadas em cenas funerárias e identificadas aos eídola dos mortos. Não há entre os dois irmãos nenhum contraste, nenhuma diferenciação: trata-se evidentemente dos gêmeos como são denominados nos textos gregos.

Em outro contexto - cenas da deposição do morto em sua tumba - Thánatos e Hýpnos revestem-se de significação especial, sem referência particular ao mito, mas ao comportamento popular das práticas funerárias sugeridas também pela função dos vasos que receberam essas pinturas - os lécitos de fundo branco - que vão se desenvolver de 470 ao final do século $\mathrm{V}$ a.C., e que se enquadram na rara categoria de recipientes com função essencialmente funerária. Até $o$ surgimento desses lécitos de fundo branco, a pratica normal era erigir estelas esculpidas sobre os túmulos. Essas esculturas, certamente dispendiosas, foram proibidas em Atenas, por volta de 487 a.C., em consequiência, sem dúvida, dos esforços igualitários da democracia ateniense. A proibição foi efetiva, de modo que as estelas esculpidas só reaparecem por volta do último quartel do séc. V a.C.. O eclipse das estelas sobre os túmulos coincide com a produção dos lécitos de fundo branco, sobre os quais muitas vezes essas estelas são pintadas, de modo que se pode concluir que estes vasos estavam também preenchendo a função dos monumentos tumulares (Bazant: 40).

$\mathrm{Na}$ verdade, esses lécitos passaram a constituir, a partir do $2^{\circ}$ quartel do séc. $\mathrm{V}$ a.C., a oferenda mais característica nos funerais de época clássica na cidade de Atenas (figura 4). $\mathrm{O}$ nome genérico - $\lambda$ ńкuӨo - designava um recipiente para conter óleo, usado com freqüência para unções do corpo em banhos, na palestra e nos ritos funerários. A partir do segundo quartel do séc. V a.C. passam a receber uma camada de pintura branca - daí a denominação de lécitos de fundo branco (onde essa cor procurava imitar o branco marmóreo das estelas funerárias) - e sobre essa camada, em rica policromia são representadas as cenas relacionadas com o mundo dos mortos: mulheres carregando cestas com as oferendas, constituídas de fitas e lécitos (Kurtz, D.C.: frontispício); oferendas nas tumbas onde se destacavam os próprios vasinhos típicos (figura 4); cenas de exposição do morto acompanhadas do lamento fúnebre (figura 5); viagem do morto para o mundo subterrâneo do deus Hades, guiado por Hermes e conduzido pelo barqueiro infernal Caronte (Pottier, pr. III).

Nessa categoria de vasos funerários não estão ausentes Morte e Sono portando o morto. Não se trata mais, como no episódio de Sarpedão, de transportar o corpo para a sua terra, a Lícia; a alusão ao mito homérico permanece apenas no esquema iconográfico, que por sua vez se acomoda às práticas funerárias atenienses. Excepcionalmente vemos esses deuses carregando $\mathrm{o}$ corpo de uma mulher, na presença de Hermes, como no exemplar do Museu Nacional de Atenas do final do séc. $V$ a.C. (Beazley, $A R V^{2}$ 1237; Vermeule: 151, fig. 4), interpretado por alguns autores como a representação dos funerais de Alceste, a heroína da tragédia de Eurípedes.

Merece destaque, nessa série, um lécito de fundo branco do Museu Britânico (figura 6), datado de 420 a.C. e de pintor anônimo a que se convencionou chamar de Pintor de Thánatos: nele vemos Morte e Sono depositando o corpo do morto em sua tumba, bem visível com seus degraus e estela, envolta com fitas votivas e tendo, na sua parte superior, a figura de um capacete de tipo coríntio, uma referência ao estatuto guerreiro do jovem morto, ricamente vestido com uma túnica bordada. A presença da tumba e a categoria do vaso insere essa cena no contexto das práticas funerárias e temos aí um episódio não mítico mas inspirado no mundo social da Atenas do séc. V a.C., com uma particularidade: o jovem guerreiro morto recebe honras de herói. Por outro lado, o pintor desse vaso evidenciou o contraste entre Thánatos e Hýpnos, representando à direita Sono com traços jovens, mas concebido em cores escuras, sombrias, numa alusão à sua natureza noturna; à esquerda, Morte, com pele clara, acrescenta a esse contraste os traços de figura mais idosa, barbada. 
$* *$

A oposição entre claro e escuro, evidenciada nas cores utilizadas pelo pintor do último lécito, conduz-nos a uma primeira vertente da tradição, a que se refere ao enigma acima mencionado sugerindo pelo texto de Pausânias em sua descrição de Noite, Morte e Sono na arca de Cípselo. Seria a criança branca (como o marfim da decoração) a representação de Thánatos; e a criança negra (escura como o cedro utilizado na confecção da arca) a figura de Hýpnos? Esse contraste, que se via no ex-voto dos Cipsélidas, obra sem dúvida de luxo e de encomenda pela prestigiosa família de tiranos da cidade de Corinto, não pode estar inteiramente dissociado da corrente intelectual, para não dizer mesmo teológica, cuja tradição se transmitia nos santuários e templos. O próprio Pausânias nos diz que, mesmo sem as inscrições ao lado das figuras que descreve, saber-se-ia identificá-las como sendo $N y ́ x$, Thánatos e Hýpnos: conhecia-se, pois, muito bem a versão hesiódica e sabia-se também, e isto no séc. II d.C., épocas em que viveu Pausânias, qual das crianças era branca ou negra.

Esse jogo entre claro/escuro transparente na iconografia de Morte e Sono, tal como se encontra na arca de Cípselo, parece articular-se com o pensamento heracliteano. Assim interpreta Cl. Ramnoux (54-61) quando cita a propósito um fragmento de Heráclito, dentre aqueles que foram transmitidos por Clemente de Alexandria: "Morte (diz o texto) é tudo que vemos desperto e tudo que vemos dormindo é sono" (fragmento 21, tradução de José Cavalcante de Souza in Os PréSocráticos, São Paulo: Ed. Abril, 1973); a Morte é clara como o despertar do dia e confunde-se com vida, o Sono é escuro como a obscuridade da Noite. Essa sabedoria, anterior mesmo a Heráclito de Éfeso, como se pode depreender pela versão da arca de Cípselo transmitida por Pausânias, marcou também o ideário imagético clássico, uma vez que a encontramos relacionada com a. concepção das figuras de Morte e Sono na arte do séc. V a.C.. Desse modo deve ser interpretado o contraste entre claro e escuro na figuração de Thánatos e Hýpnos sobre o lécito funerário do Museu Britânico (figura 6).

Uma segunda tradição manifesta-se na arte figurativa de Thánatos e Hýpnos: aquela que se inspira na épica, cujo modelo homérico dos funerais de Sarpedão repercute, não apenas através de um esquema imagético fiel ao episódio mítico como na cratera de Eufrônio (figura 2) e provavelmente no exemplar do Louvre (figura 3), mas também com variações inspiradas nos rituais funerários praticados pelos atenienses, tal como é transmitida nos lécitos de fundo branco. Aqui a memória do mito de Sarpedão se projeta num contexto mais amplo de prática funerária em que se evidencia a crença na heroicização do morto, privilegiado pelo translado à tumba, por mãos de deuses que personificam Morte e Sono.

No quadro dessas conclusões, a imagem do lécito de fundo branco do Museu Britânico (figura 6) reveste-se de uma significação maior na medida em que reúne as duas tradições iconográficas referentes a Morte e Sono: de um lado a versão contrastada dessas duas entidades divinas, assim como transparece na concepção da arca de Cípselo transmitida por Pausânias e no pensamento de Heráclito de Éfeso; de outro lado, a versão heróica que repete o esquema iconográfico épico visível na cratera de Eufrônio (figura 2) e projetado para funerais de mortos heroicizados.

\section{Referências bibliográficas}

BAZANT, J. - Entre la croyance et l'expérience: le mort sur les lécythes à fond blanc, in KAHIL, L. - AUGÉ, CHR. - LINANT DE BELLEFONDS, P. (dir.) - Iconographie classique et identités régionales. BCH. Supplément XIV. Paris: De Boccard, 1986, p. 37-44.

BEAZLEY, J. D. - Attic Red-Figure Vase Painters. (2a. ed.) Oxford: Clarendon Press, 1963, 3 vols. 
EGER, C. - Le Sommeil e la Mort dans la Grèce antique. Paris: Ed. Picard, 1966.

KURTZ, D. C. - BOARDMAN, J. - Greek Burial Customs. London: Thames and Hudson, 1971.

KURTZ, D. C. - Athenian White Lekythoi. Patterns and Painters. Oxford Monographs on Classical Archaeology. Oxford: Clarendon Press, 1975.

LACROIX, L. Pausanias, le coffre de Kypselos et le problème de l'exégèse mythologique . RA 2, 1988, 243-261.

MANOLDI, C. Sono e morte in Grecia antica. In: RAFFAELLI, R. (a cura di) Rappresentazioni della Morte. Urbino: Ed. Quattro Venti, 1987, 7-46.

POTTIER, E. Étude sur les Lécythes Blancs Attiques à Représentations Funéraires. BEFAR, 30, Paris: Ernest Thorin, 1883.

RAMNOUX, C. La Nuit et les Enfants de la Nuit dans la Tradition Grecque. Paris: Flammarion, 1959.

SCHEFOLD, K. Myth and Legend in Early Greek Art. London: Thames and Hudson, 1966.

SHAPIRO, A. The Origins of Allegory in Greek Art. Boreas 9, 1986, 4-23.

SHAPIRO, A. Personifications in Greek Art. Zürich: Akanthns, 1993.

SOURVINOU-INWOOD, C. Images grecques de la mort: représentations, imaginaire, histoire. AION9, 1987, 146-158.

VERMEULE, E. Aspects of Death in Early Greek Art and Poetry. Berkeley, Los Angeles, London: University of California Press, 1979.

VERNANT, J. P. Aspectos da pessoa na religião grega. Mito e Pensamento entre os gregos: estudos de picologia histórica. Tradução de Haiganuch Sarian, São Paulo: DIFEL/EDUSP, 1973, 277-291.

SARIAN, H. Mort e Sommeil dans l'art grec: notes d'iconographie funéraire. Classica, São Paulo, 7/8: 63-74, 1994-1995.

RÉSUMÉ: Mort et Sommeil ont expressions figuratives dans l'art grec et, par une
comparaison avec la tradition littéraire, nous éclairons des croyances, une
élaboration poétique et un comportement religieux. Sont analysés des textes
d'Hésiode, d'Héraclite et de Pausanias, en plus la version homérique sur la
mort de Sarpédon. Quelques témoins dans l'art grec céramique des Vle. et Ve.
siècles av. J. C. indiquent deux traditions iconographiques concernant Mort et
Sommeil: une version contrastée de ces deux entités divines transmise par le
coffre de Cypsélos dans la mention de Pausanias et par Héraclite d'Ephèse; la
version heroïque, homérique, dont l'exemplaire imagé le plus important est le
cratère d'Euphronios. MOTS CLÉS: Thánatos, Hýpnos, art grec, tradition iconographique, tradition littéraire, iconographie funéraire. 


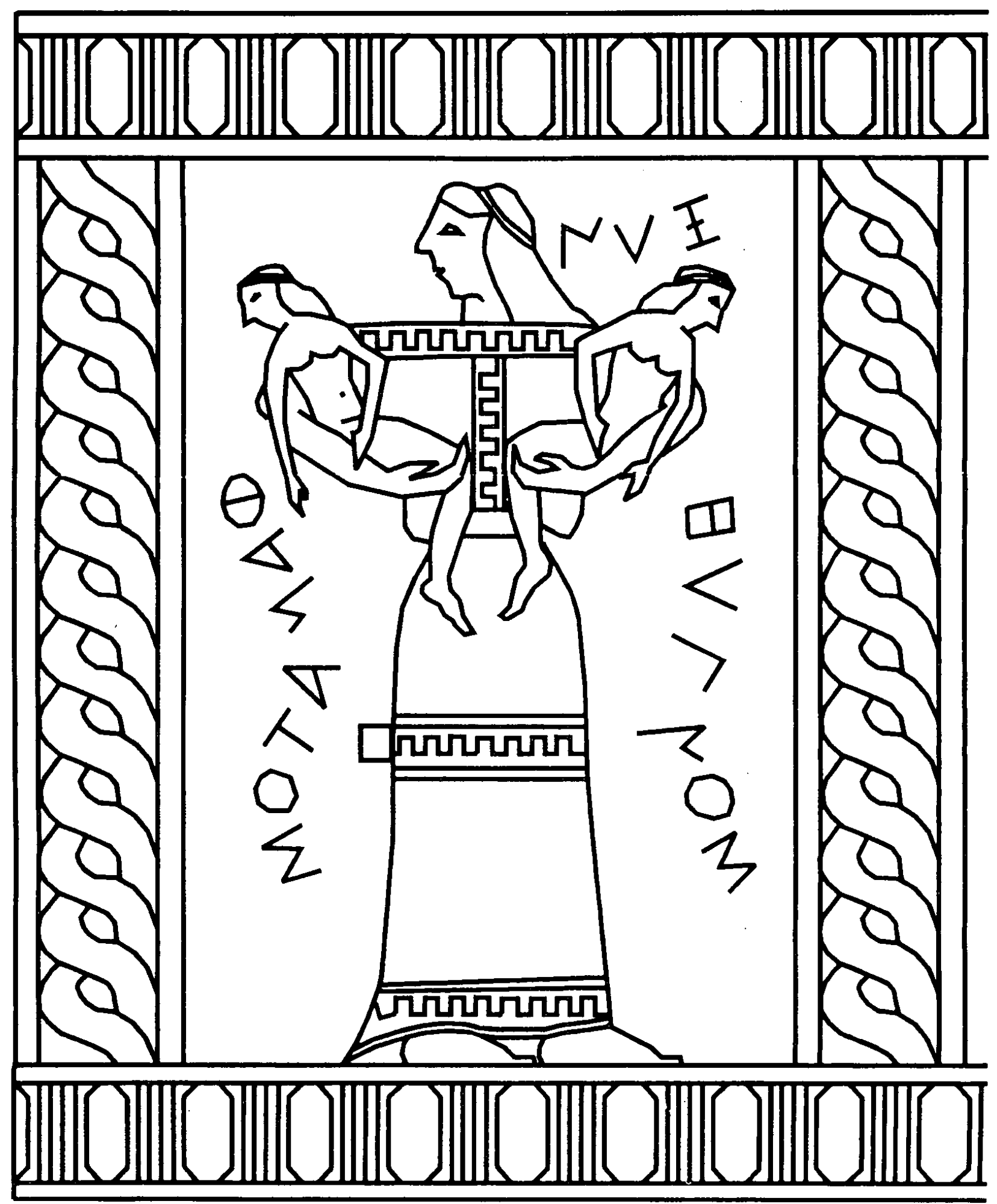

Figura I: Noite segurando nos braços Morte e Sono. Pormenor da arca de Cípselo, 570 a.C.. Reconstituição. 


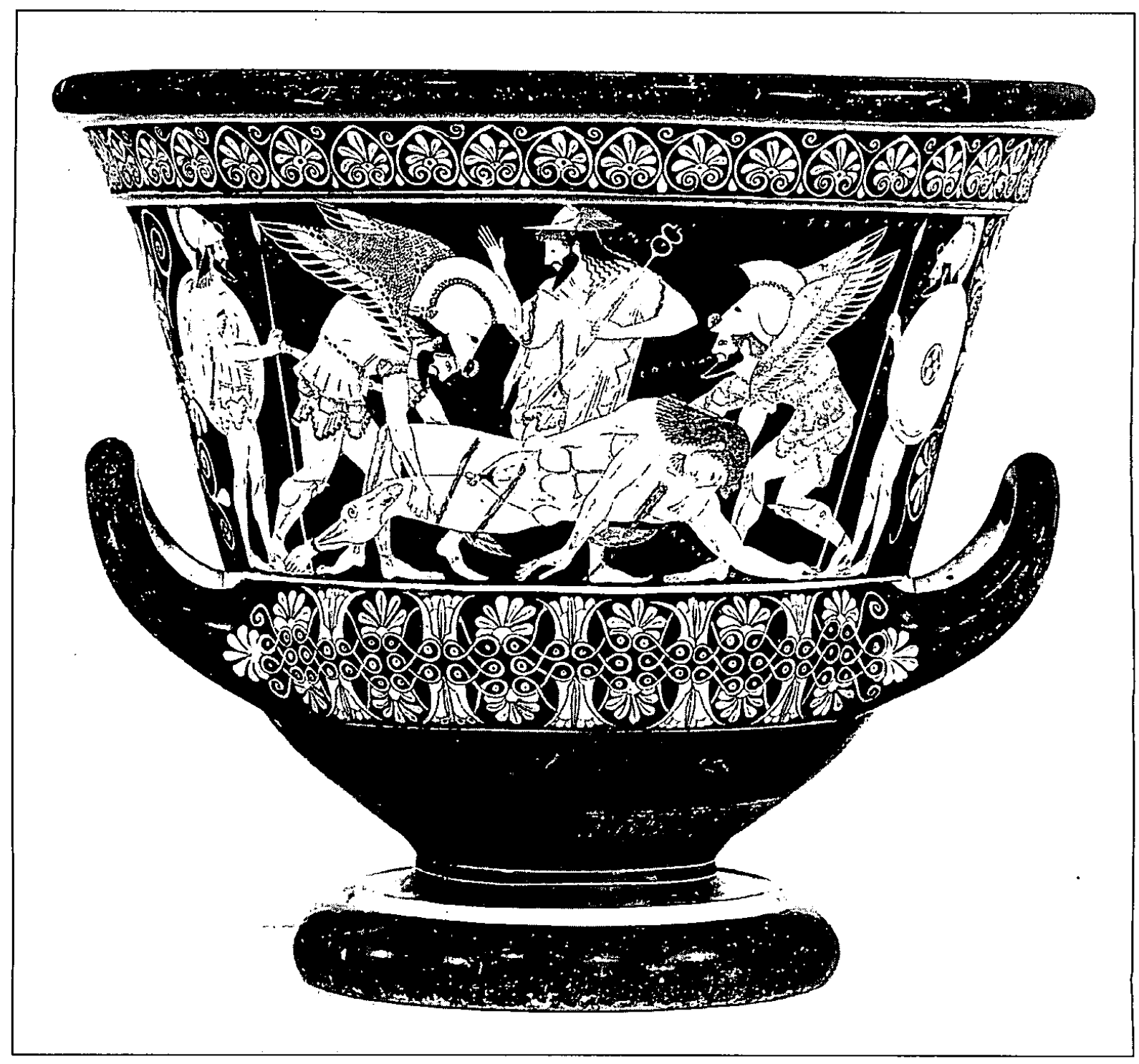

Figura 2: Morte e sono transportando o corpo de Sarpedão na presença de Hermes e de dois guerreiros. Cratera ática de figuras vermelhas, 510 a. C. Nova Iorque, The Metropolitan Museum of Art, Pintor Eufrônio, oleiro Euxiteo. 


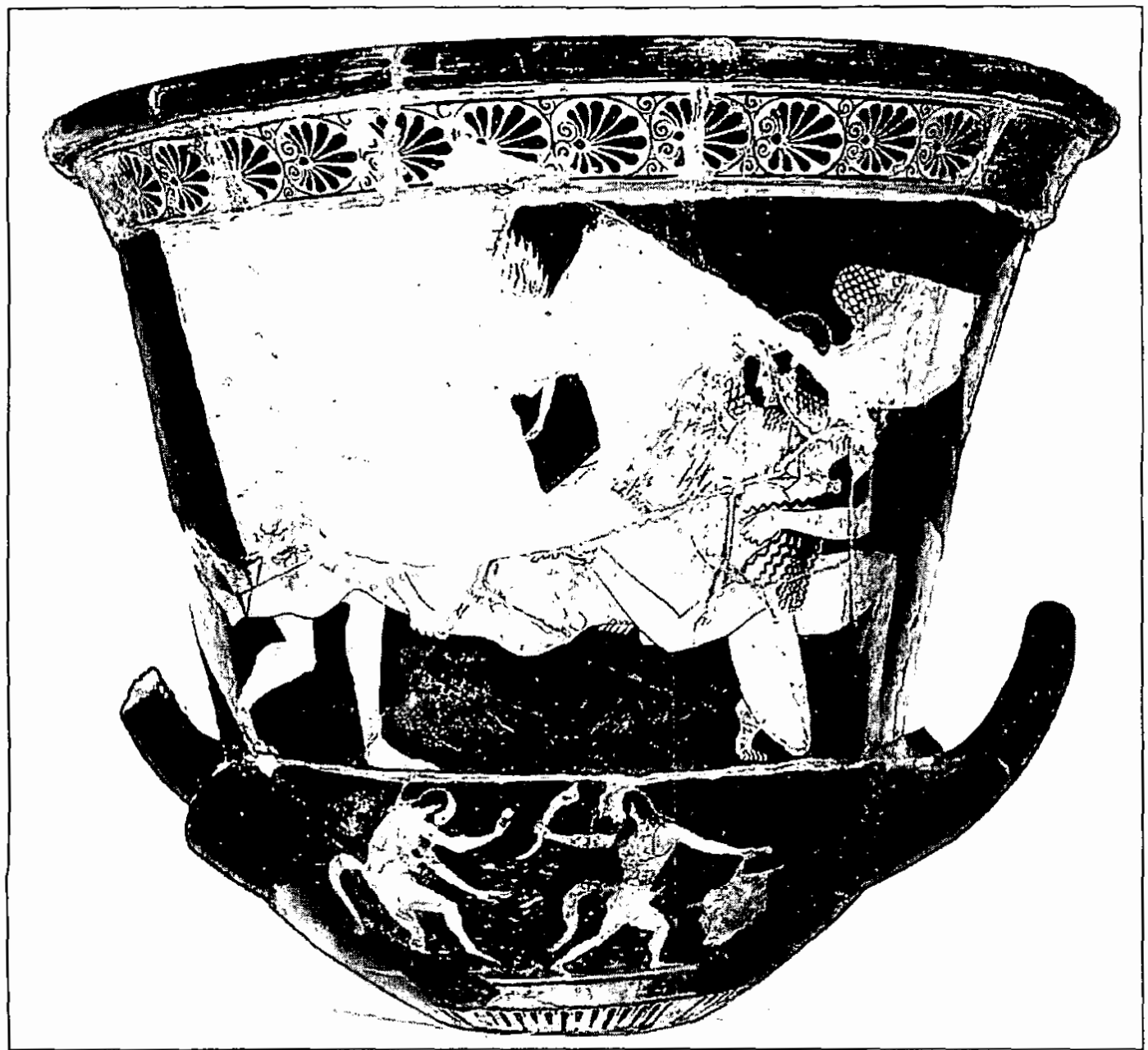

Figura 3: Morte e Sono transportando o corpo de um herói, possivelmente Sarpedão. Na zona inferior, Sátiros dançando. Cratera ática de figuras vermelhas, primeira metade do séc. $V$ a.C.. Paris, Museu do Louvre, inv. $n^{\circ}$ G 163 (Beazley, ARV ${ }^{2} 227,12$, The Eucharides Painter). 


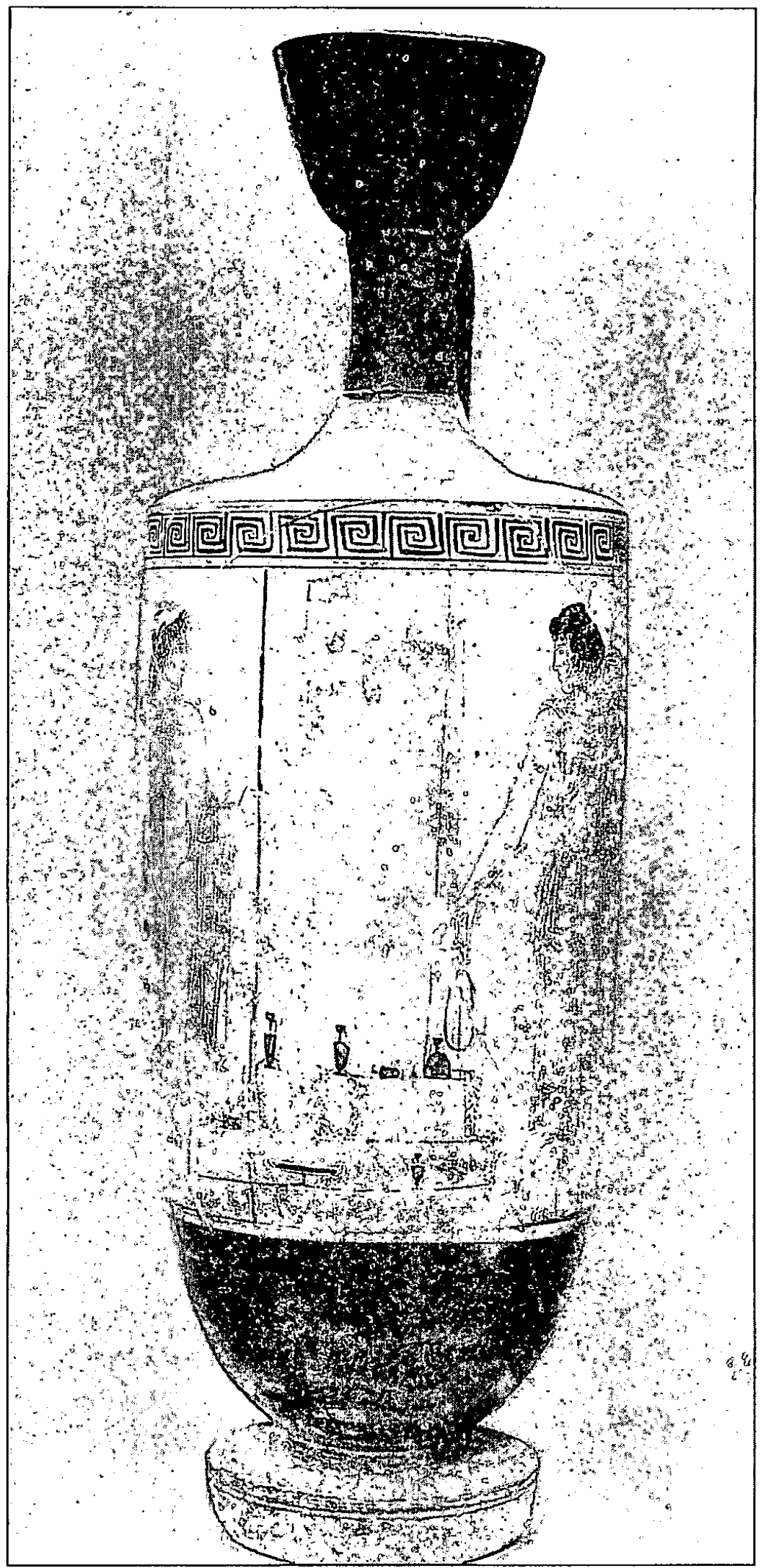

Figura 4: Oferendas junto à tumba. Lécito ático de fundo branco, 450-400 a.C., Nova Iorque, The Metropolitan Museum of Art, Rogers und, 1923. Inv. $n^{\circ}$ 23.160.38(Beazley, ARV², 1227, The Bosanquet Painter). 


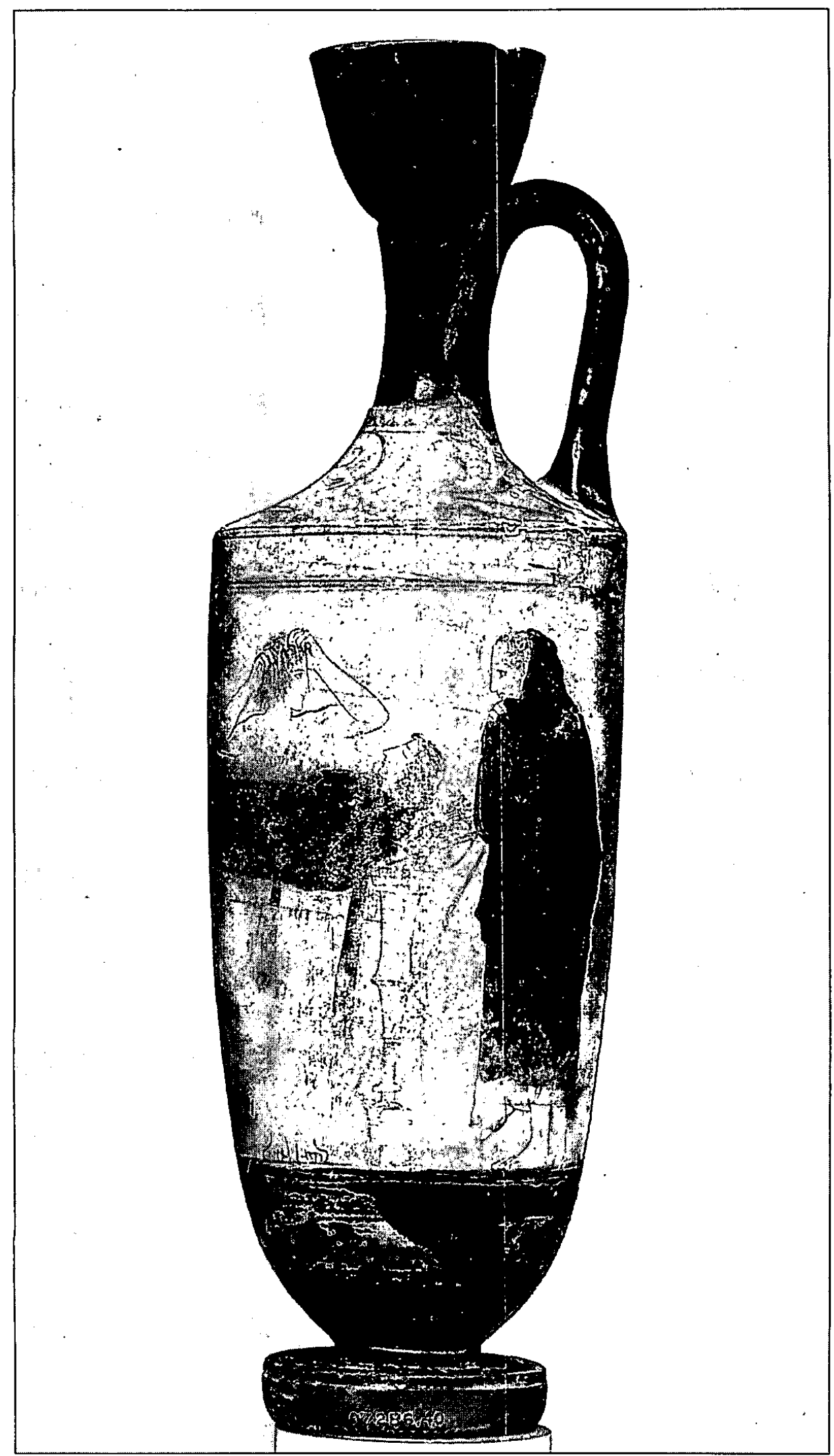

Figura 5: Exposição e lamentação do morto. Lécito ático de fundo branco, terceiro quartel do séc. Va.C.. Nova Iorque, The Metropolitan Museum of Art, inv. $n^{\circ} 07.286 .40$ (Beazley, $\mathrm{ARV}^{2}, 846$, The Sabourof Painter). 

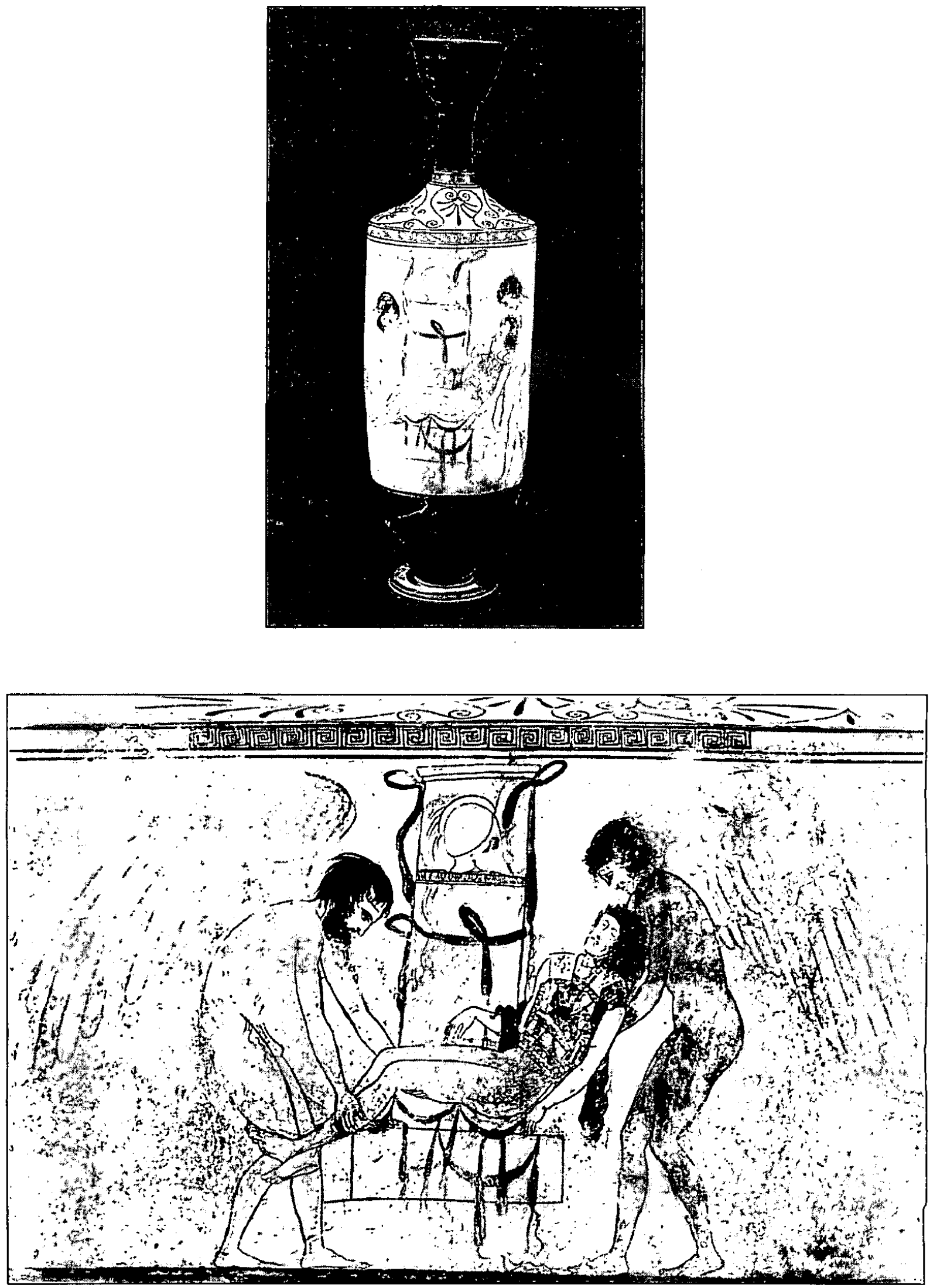

Figura 6: Morte e Sono depositando o corpo do morto na tumba. Lécito ático de fundo branco, 420 a.C. Londres, The British Museum, inv. $n^{\circ}$ D58(Beazley, $\mathrm{ARV}^{2}, 1228$, The Thanatos Painter). 